\title{
CASTRO ALVES EM LIVRO, VÍDEO E TEATRO - RELANÇAMENTO DAS OBRAS COMPLETAS DO POETA
}

\author{
Paulo Paniago
}

\begin{abstract}
Relançamento das obras completas pela Nova Aguilar, vídeo de Sílvio Tendler e montagem de peça por Marcelo Souza marcam sesquicentenário do poeta
\end{abstract}

Castro Alves Obra Completa, da Nova Aguilar, está sendo relançada em edição comemorativa do sesquicentenário. Organizada por Eugênio Gomes, essa edição especial ganhou uma nota extra, assinada por Alexei Bueno, que explica: "uma nova revisão pôde corrigir as poucas inexatidões que ainda persistiam, transformando-a na mais correta obra integral do poeta dos escravos" Na verdade, trata-se de correção da segunda edição, que está sendo impressa pela terceira vez. A primeira edição, é bom lembrar, é de 1960.

Além das obras de poesias (Espumas Flutuantes, Os Escravos, A Cachoeira de Paulo Afonso, Gonzaga), o volume único apresenta seus textos em prosa, uma alentada seção de notas e variantes, e, como apêndice, um diálogo (travado em cartas) entre José de Alencar e Machado de Assis, acerca de Gonzaga ou A Revolução de Minas, o drama composto por Castro Alves por sua musa, a atriz Eugênia Câmara.

Sobretudo, o livro permite conhecer outros poemas de Castro Alves que não os muitos divulgados como $O$ Navio Negreiro. É possível perceber, então, as desigualdades de um poeta que primou pela intensidade da vida, transposta para sua poesia. Assinado por Jorge Amado, $A B C$ de Castro Alves continua um campeão de vendas, tendo passado da $30^{\mathrm{a}}$ edição.

Filme Em fase de pré-produção, Sílvio Tendler deve começar as filmagens de seu curta-metragem sobre Castro Alves em março. Com quinze minutos de duração, Tendler fala que a vida de Castro Alves fornece material para um longa, mas que vai enfrentar o desafio de fazer uma "grande síntese" O roteiro, do próprio Tendler, foi apresentado ao Instituto Cultural Itaú, que financia uma parte da produção. 
"Sempre tive vontade de filmar Castro Alves, porque ele teve uma vida fantástica", declara o documentarista, que deve usar atores e mudar o estilo tradicional de narrativa de documentários. "Um sujeito que nasce como poeta aos doze anos e morre aos 24, era ousado e atrevido, dizia coisas como 'sinto em mimo borbulhar do gênio algo que só ele, Darcy Ribeiro e Glauber Rocha, teriam coragem de dizer; um poeta assim é ótimo para se discutir a importância do artista no mundo"

O elenco ainda está sendo escolhido, mas a decisão mais premente para Tendler são as locações, uma vez que Castro Alves nasceu por Salvador, Recife, Rio de Janeiro e São Paulo.

Selo Um selo com a imagem de Castro Alves, a imagem de Salvador, de uma cena de castigo em praça pública e de um trecho do poema $O$ Navio Negreiro, será lançado dia 14 de março, exatamente 150 anos depois da data de nascimento do poeta condoreiro, considerado o último romântico brasileiro.

Peça - Marcelo Souza, diretor de teatro, exercendo atualmente função de chefe de gabinete do diretor da Fundação Cultural, está em fase de pré-produção da peça $O$ Condor, um texto da carioca Ana Maria Nunes. Os atores Luís Guilherme Baptista e Marília Barbosa já estão envolvidos com a peça, que deve estrear no final de agosto ou início de setembro. A peça conta a história de Castro Alves "de maneira teatral" conforme definição do diretor, que dá um quadro geral: "Há, claro, a poesia, mas também a paixão pela atriz Eugênia Câmara e a relação com o abolicionismo. Castro Alves era juvenil, superficial, um abolicionista de primeira hora"

Castro Alves Obra Completa, de Castro Alves. Rio de Janeiro, Nova Aguilar, 1997, 910 p. Organização de Eugênio Gomes. 